\title{
Molecular targeting of angiogenesis for imaging and therapy
}

\section{Journal Article}

Author(s):

Brack, Simon S.; Dinkelborg, Ludger M.; Neri, Dario (i)

Publication date:

2004-09

Permanent link:

https://doi.org/10.3929/ethz-b-000049274

Rights / license:

In Copyright - Non-Commercial Use Permitted

Originally published in:

European Journal of Nuclear Medicine and Molecular Imaging 31(9), https://doi.org/10.1007/s00259-004-1648-0 


\title{
Molecular targeting of angiogenesis for imaging and therapy
}

\author{
Simon S. Brack ${ }^{1}$, Ludger M. Dinkelborg², Dario Neri ${ }^{1}$ \\ 1 Institute of Pharmaceutical Sciences, Department of Chemistry and Applied Biosciences, Swiss Federal Institute of Technology Zurich, \\ Zurich, Switzerland \\ ${ }^{2}$ Research Laboratories of Schering AG, Berlin, Germany
}

Published online: 5 August 2004

(C) Springer-Verlag 2004

\begin{abstract}
Angiogenesis, i.e. the proliferation of new blood vessels from pre-existing ones, is an underlying process in many human diseases, including cancer, blinding ocular disorders and rheumatoid arthritis. The ability to selectively target and interfere with neovascularisation would potentially be useful in the diagnosis and treatment of angiogenesis-related diseases. This review presents the authors' views on some of the most relevant markers of angiogenesis described to date, as well as on specific ligands which have been characterised in pre-clinical animal models and/or clinical studies. Furthermore, we present an overview on technologies which are likely to have an impact on the way molecular targeting of angiogenesis is performed in the future.
\end{abstract}

Keywords: Angiogenesis - Targeting - Antibody Cancer - Chronic inflammation

Eur J Nucl Med Mol Imaging (2004) 31:1327-1341

DOI 10.1007/s00259-004-1648-0

\section{Ligand-based targeting of disease: general concepts}

\section{Targeting}

The vast majority of approaches for the treatment of disease are limited by lack of specificity. This constraint holds true for many diseases, but it is most evident in the treatment of solid tumours, where most chemotherapeutic agents exhibit poor accumulation in the tumour mass owing to poor blood perfusion, irregular vasculature and

\footnotetext{
Dario Neri ( $)$

Institute of Pharmaceutical Sciences,

Department of Chemistry and Applied Biosciences,

Swiss Federal Institute of Technology Zurich,

Winterthurerstrasse 190, 8057 Zurich, Switzerland

e-mail: neri@pharma.ethz.ch

Tel.: +41-1-6356063, Fax: +41-1-6356886
}

high interstitial pressure in the tumour environment [1, 2]. Moreover, multidrug resistance proteins may further decrease drug uptake. As a consequence, the development of therapeutic agents which preferentially accumulate in solid tumours represents a main focus of modern anticancer research.

Since Paul Ehrlich first envisioned the possibility of selective delivery of antibodies to the tumour environment at the end of the nineteenth century, the concept of "magic bullets" capable of tumour targeting has been extended to other molecules (peptides, small organic molecules, etc.) capable of selective localisation in the tumour environment. After some delay following the invention of hybridoma technology [3], several monoclonal antibodies have been approved by the US Food and Drug Administration (http://www.fda.gov) and in Europe, both for the imaging of disease and for therapeutic applications.

The synergy between imaging opportunities and therapeutic applications is one of the main attractions of biomedical approaches which rely on the selective delivery of bioactive molecules to the tumour environment. In principle, the same binding moiety (e.g. a monoclonal antibody) can be used for the delivery of agents which facilitate tumour detection (radionuclides, fluorophores) or agents capable of triggering a biocidal event (radionuclides, photosensitisers, drugs, cytokines, pro-coagulant factors, etc.). Quantitative biodistribution studies in animals and imaging studies in patients are invaluable tools for the characterisation of markers of diseases (e.g. tumour-associated antigens) and of the corresponding ligands (e.g. monoclonal antibodies). Indeed, ligand-based targeted therapeutic strategies may represent one of the few areas of pharmaceutical research in which the performance of a therapeutic strategy can be monitored at several stages of the development process. Whenever unsatisfactory targeting results are observed in biodistribution or imaging studies, these data urge the researchers to use better target antigens and/or better ligands in their pharmaceutical strategy. Furthermore, imaging of the target molecule responsible for therapy allows for individualised patient selection and early monitoring of the therapeutic intervention. 
The importance of antigen quality in ligand-based targeted imaging or therapeutic strategies cannot be overstated. In theory, an ideal target should be specific, easily accessible, stable and abundant. In practice, few antigens exhibit all these properties, but (as we will see in "Angiogenesis-related disorders") markers of angiogenesis may combine a number of attractive features, such as excellent accessibility, low expression in normal adult tissues and over-expression in several relevant pathologies, including cancer.

\section{Angiogenesis}

Angiogenesis, i.e. the sprouting of new blood capillaries from existing vessels, is an essential process for embryonic development. Once the vascular network is in place, endothelial cells remain quiescent and angiogenesis is triggered only locally and transiently during a number of physiological conditions like the female reproductive cycle, wound healing or hair growth [4]. Angiogenesis is a tightly controlled multi-step process, in which pro-angiogenic and anti-angiogenic factors are in equilibrium to neutralise one another. Imbalance of this equilibrium, due to either upregulation of pro-angiogenic or downregulation of anti-angiogenic mediators, induces angiogenesis.

Angiogenesis is an important feature of a range of pathological conditions, cancer being one of the most prominent examples [5] (see "Angiogenesis-related disorders"). The growth of new capillaries is often triggered in conditions of pathological cellular proliferation, ischaemia or chronic inflammation, where an increase in blood supply may compensate for hypoxia and insufficient delivery of nutrient to the tissue $[6,7]$. Unlike the situation in physiological conditions, blood vessels grow unabated in cancer and other pathologies, and tumour angiogenesis sustains the progression of the disease.

During angiogenesis, endothelial cells detach from the pre-existing destabilised vessel, migrate into the perivascular space and proliferate to finally mature and form new vascular structures. A number of growth factors, proteases, adhesion molecules and other angiogenic mediators which enable endothelial cell migration or proliferation regulate this process. Vascular endothelial growth factor (VEGF) is considered one of the most important growth factors in angiogenesis [8]. It increases the permeability of existing blood vessels and acts as an endothelial cell survival factor, as well as being a potent endothelial cell mitogen. The neutralising humanised monoclonal anti-VEGF antibody bevacizumab (Avastin, Genentech) has recently been approved for the treatment of colorectal cancer [9], but showed no survival benefit in patients with breast cancer [10].
Ligands to markers of angiogenesis

and their applications in targeting

In this review, we will refer to "targeting" as the selective delivery of a molecular agent to a site of disease. In most cases, this molecular agent will be a ligand specific to a target antigen ("marker") which is over-expressed at the site of disease. At present, monoclonal antibodies are the only clinically proven class of high-affinity binding molecules which can be generated against virtually any marker of disease. However, as we will see in "Ligands for targeting applications", other molecular species (such as peptides, aptamers, or small organic molecules) are also being considered for targeting applications.

Monoclonal antibodies exhibit slow elimination from the blood and accumulate predominantly in the liver. Rapidly clearing antibody fragments are typically preferred for imaging applications in nuclear medicine. By contrast, intact immunoglobulins continue to represent the antibody format of choice for many therapeutic applications [11], which rely on the antibody's ability to interfere with signalling events and to activate antibody-dependent cellular cytotoxicity mechanisms or complement.

The immunogenicity of rodent antibodies continues to be a concern for repeated administrations to humans, and the use of chimeric, humanised or fully human antibodies is generally preferred $[11,12]$.

Markers of angiogenesis can be located on the luminal or abluminal aspects of new blood vessels (Fig. 1). Components of the modified extracellular matrix are mostly found on the abluminal side of neovasculature. These antigens are often stable and abundant. Some extracellular matrix components (such as oncofetal fibronectins and tenascins) display a restricted pattern of expression and may serve as useful antigens for tumour targeting applications. In spite of the fenestration of tumour blood vessels, the ligand-based targeting of abluminal antigens can be a slow process owing to the irregular vasculature and high interstitial pressure of solid tumours, as well as to the fact that such ligands must extravasate in order to reach their target.

While markers of angiogenesis on the luminal side of new blood vessels are better accessible, it would be misleading to consider that they will necessarily lead to faster, more efficient ligand-based targeting applications. The targeting of such antigens, by means of a rapidly clearing ligand (e.g. an antibody fragment), can be viewed essentially as a single-compartment pharmacokinetic problem. A small antibody fragment with a low kinetic dissociation constant for the antigen will have two main possible fates: it will either bind to the accessible target or be cleared from the circulation via the renal and hepatobiliary route. In this model, the time required for semisaturation of the target antigen satisfies the following equation:

$T_{1 / 2}=\ln 2 /\left(k_{o n}[A b]\right)$ 
Fig. 1. Schematic representation of the tumour neovasculature as a target for biomedical intervention. Markers of angiogenesis can be located on the luminal (blue) or the abluminal (green) aspect of new blood vessels. Proteins of the extracellular matrix are mainly situated on the abluminal side, possibly impairing their accessibility from the bloodstream. However, while markers on the luminal side are better accessible, they may be less abundant and less stable

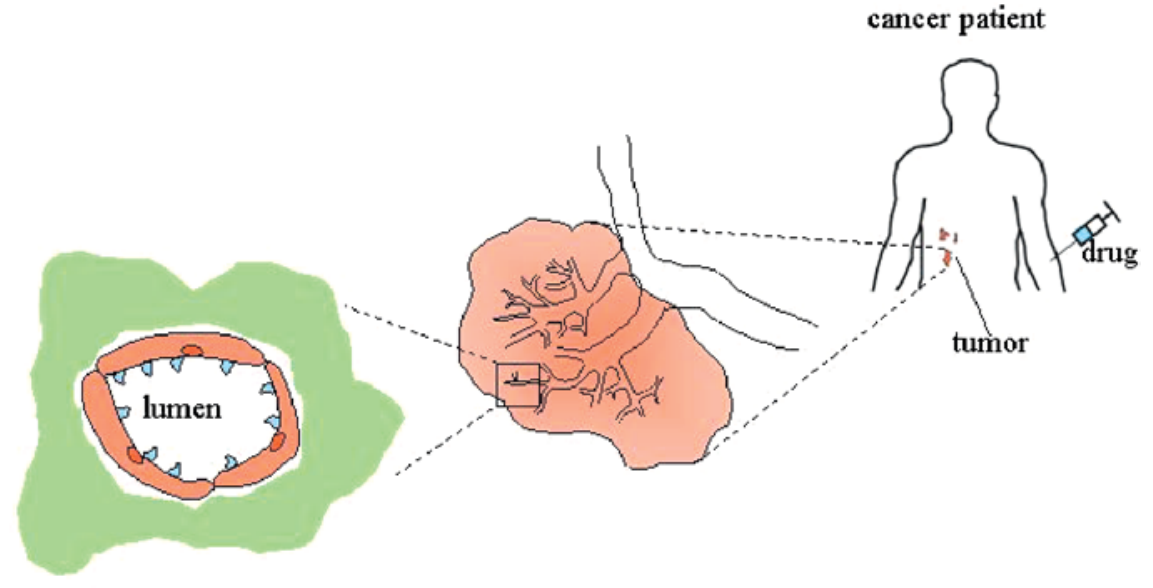

where $k_{\text {on }}$ is the kinetic association constant of the antibody for the antigen and $[\mathrm{Ab}]$ is the initial antibody concentration in blood, neglecting blood clearance (which obviously can only make the targeting process even less efficient).

From Eq. 1, it is obvious that an accessible luminal target can be saturated very rapidly if high concentrations of ligands are used (e.g. $T_{1 / 2}=0.692 \mathrm{~s}$ if $k_{\mathrm{on}}=10^{6} \mathrm{M}^{1} \mathrm{~s}^{-1}$ and $[\mathrm{Ab}]=1 \mu M)$. However, such rapid targeting results will correspond to only a minimal fraction of antibody being used for targeting (and will translate into very poor percent injected dose per gram of tissue), unless the target antigen is abundantly expressed. In fact, saturation of target antigen leaves most of the remaining antibody in circulation (leading to poor tumour/blood ratios). Such a targeting scenario will not be satisfactory for applications in nuclear medicine, as the performance of radiolabelled antibodies for imaging and radioimmunotherapy applications relies strongly on the achievement of high tumour/organ ratios.

Lowering the initial antibody concentration to levels that stoichiometrically match the amounts of accessible antigen does not help. Even with exceptionally high affinity antibodies, the ultimate diffusion-controlled limits on $k_{\text {on }}$ values make it impossible to rapidly target lowabundance accessible antigens with low (e.g. subnanomolar) concentrations of ligands.

We anticipate that a combination of several parameters, such as blood circulation properties, vascular integrity, antigen abundance, tumour size and ligand $k_{\text {on }}$ values, will crucially influence the targeting efficiency for markers located on the luminal aspect of new blood vessels.

\section{Angiogenesis-related disorders}

Cancer

Most of the current knowledge about angiogenesis stems from investigations on tumoural angiogenesis. A large number of molecules involved in angiogenesis have been first identified in tumours and later confirmed in other pathological conditions.

Many tumours in humans persist in situ without being accompanied by angiogenesis $[13,14]$. At that stage they tend to be clinically undetectable and are rarely larger than 1-2 $\mathrm{mm}$ in diameter because diffusion of oxygen and nutrients limits their size. The high rate of proliferation in these tumours is compensated by abundant internal apoptosis as a consequence of insufficient blood supply.

As the tumour adopts an angiogenic phenotype, the balance between pro-angiogenic and anti-angiogenic factors is upset and angiogenesis is triggered. The tumour mass is allowed to overtake the apoptotic rate and expands. This process is referred to as "angiogenic switch" $[5,15]$. Not only is angiogenesis required for tumours to grow beyond a certain size, but it also enables tumour cells to migrate into surrounding tissue and to colonise distant sites, forming metastases. Metastases again can only grow to a threatening size if the metastatic cells are able to trigger angiogenesis [5].

Although the mechanisms eliciting the angiogenic switch are not entirely understood to date, it is believed that besides tumour-suppressor mutation and oncogene activation, hypoxia plays a pivotal role [16]. There are at least two hypoxia-dependent regulatory mechanisms which lead to VEGF expression. The first mechanism relies on the transcription factor hypoxia-inducible factor (HIF-1), which controls VEGF transcription [17]. The alpha subunit of HIF-1, HIF-1 $\alpha$, is degraded under normoxic conditions and stabilised under hypoxia $[6,18$, 19]. Second, VEGF mRNA becomes stabilised under hypoxic conditions [20]. VEGF concentrations stimulate proliferation of endothelial cells, which in turn produce many unspecific angiogenic stimulators, including basic fibroblast growth factor (bFGF), acid fibroblast growth factor (aFGF), transforming growth factor $\alpha$ and $\beta$ (TGF $\alpha$ and TGF $\beta$ ) and platelet-derived endothelial cell growth factor (PD-ECGF). Additionally, tumour cells produce proteases, among which are matrix metallopro- 
teinases (MMP) and serine proteases like urokinase plasminogen activator (uPA) or tissue plasminogen activator. Endothelial cells display cell adhesion molecules such as integrins $\alpha_{v} \beta_{3}$ and $\alpha_{v} \beta_{5}$ which mediate interaction with the extracellular matrix. Laminin, type IV collagen and tenascin are synthesised to constitute the new basement membrane.

Reduced oxygen tension promotes angiogenesis not only by stimulating the production of inducers but also by reducing the production of inhibitors. Thrombospondin-1 was the first angiostatic protein for which anoxiatriggered downregulation during tumourigenesis was demonstrated [21]. Since then, a number of endogenous angiogenesis inhibitors have been identified.

The tumour vessels differ from their normal counterparts: architecturally, they are irregularly shaped, dilated and tortuous, and even contain dead ends [22]. Extensive fenestration, an abnormal basement membrane and unusually wide gaps between adjacent endothelial cells make them leaky [23-25].

The treatment of cancer with an anti-angiogenic approach was first proposed more than two decades ago [13]. Accordingly, various anti-angiogenic strategies have been investigated pre-clinically. This extensive research has culminated in the recent approval of bevacizumab (Avastin, Genentech) as first-line treatment for metastatic colon carcinoma $[9,26]$.

\section{Age-related macular degeneration (ARMD) and proliferative diabetic retinopathy}

Ocular neovascularisation is associated with many ocular diseases and is responsible for the majority of cases of irreversible blindness in the developed world. Abnormal ocular angiogenesis may ultimately cause severe vitreous cavity bleeding, retinal detachment and glaucoma leading to blindness. Proliferative diabetic retinopathy and age-related macular degeneration (ARMD), which are the two most common angiogenesis-related eye diseases, are therefore of high socio-economic impact [27].

The stimulus giving rise to diabetic retinopathy is unknown, but it is likely that hyperglycaemia leads to vascular abnormalities and to ocular ischaemia, a process which probably involves leucocytes or platelets [28-30]. The hypoxic portions of the retina release VEGF, which in turn promotes pathological vasoproliferation in the retina [31, 32]. Recently, an angiogenic inhibitor responsible for the avascularity of the cornea and the vitreous was identified as pigment epithelium-derived factor and found to be deficient in diabetic retinopathy $[33,34]$. Inhibition of VEGF with a soluble VEGF receptor chimeric protein was found to suppress retinal neovascularisation in a mouse model [35]. A number of strategies based on VEGF inhibition are currently undergoing clinical investigation.

ARMD is the main cause of blindness in elderly people. Macular degeneration refers to the breakdown of cells in the centre of the retina. Ten percent of ARMD patients are affected by choroidal neovascularisation, which is responsible for most of the vision loss [27]. Vessels arising from the choroidal vasculature grow into the plane of the retinal pigment epithelium and sub-retinal space. This occurs nearly exclusively in the macular and perimacular regions of the retina. The newly formed vessels are structurally weak and lack integrity, which results in loss of photoreceptors. As with diabetic retinopathy, the causes of ARMD have not yet been elucidated. Besides local tissue hypoxia as a consequence of local ischaemia, inflammation has been implicated in ARMD [36].

\section{Psoriasis}

Psoriasis is a chronic inflammatory skin disease that affects approximately $1-3 \%$ of the Western population [37]. Clinically psoriasis appears as symmetrical, welldemarcated erythematous plaques topped with silvery white scales, most commonly on the scalp, knees, elbows and trunk. Although rarely fatal, it severely impairs quality of life. The disease is characterised by hyperproliferation of keratinocytes, infiltration of inflammatory cells and increased cytokine levels. The lastmentioned are responsible for activation of keratinocytes and lymphocyte invasion by cytokine-mediated upregulation of adhesion molecules on endothelial cells.

Psoriasis is accompanied by expansion of the superficial dermal microvasculature and elongation of capillary loops passing into the dermal papillae and the papillary tip [38]. Although angiogenesis may not be a primary event in psoriasis, it occurs at an early stage. Several angiogenic stimuli have been implicated in psoriasis: proangiogenic VEGF and IL-8 expression was found to be upregulated while thrombospondin-1 was downregulated in epidermal keratinocytes [39-41]. Aberrant expression of a wide range of angiogenic molecules in psoriatic skin has been reported in the literature, these molecules including integrin $\alpha_{v} \beta_{3}$, angiopoietin-2, TGF $\alpha$ and IL-15 [42-45]. As early as 1972, it was recognised that psoriasis therapy could rely on inhibition of angiogenesis [46]. Current medications for psoriasis possess a certain antiangiogenic activity, e.g. cyclosporin A or retinoids [47, 48].

\section{Rheumatoid arthritis}

Rheumatoid arthritis (RA) is a chronic destructive musculoskeletal autoimmune disorder associated with thickening of the synovial membrane lining the joints, inflammation, hyperproliferation of synovial cells and formation of a proliferating pannus. It involves a pro-inflammatory cytokine cascade, leucocyte invasion, damage of the affected cartilage and joints and bone erosion. The 
extensive hyperplasia of the synovium requires a compensatory increase in the number of blood vessels to nourish and oxygenate the tissue. Hence, angiogenesis is central in the pathological course of RA.

Over-expression of a number of angiogenic factors is responsible for a pro-angiogenic imbalance in RA. VEGF is expressed in RA synovium and elevated in the serum of RA patients. Serum levels of VEGF further correlate with disease activity, and improvement in the clinical symptoms of RA is associated with a reduction in VEGF levels. Inactivation of VEGF has been exploited as a therapeutic approach for RA therapy [49, 50].

Other pro-angiogenic factors like tumour necrosis factor-alpha (TNF $\alpha)$, IL-1, or TGF $\beta$ are elevated in the synovial fluid of RA patients, and their blockade has also evolved as a strategy for the treatment of RA [51-53]. The most promising therapies available nowadays are TNF $\alpha$-neutralising molecules. Anti-TNF $\alpha$ therapy has been found to ameliorate essentially all aspects of RA and, importantly, halts joint destruction; it has become the standard for RA therapy [54].

\section{Markers of angiogenesis}

\section{Markers of angiogenesis for vascular targeting}

A number of protein antigens expressed either in the vessel or in the adjacent matrix of the vessel have been characterised as targets for the selective delivery of antibodies (or peptides) to the tumour neovasculature. For some of these markers, both clinical and pre-clinical data are already available. This section presents the authors' views on the most promising tumour vascular targets which have been characterised in the recent past. The list of antigens includes proteins which are preferentially expressed on the surface of endothelial cells in tumour blood vessels, as well as components of the modified extracellular matrix which surrounds the tumour neovasculature.

\section{Fibronectin extra-domain B}

Fibronectin is a large glycoprotein, which is present in large amounts in plasma and tissues. The extra-domain B of fibronectin (EDB) is a domain of 91 amino acids which, in normal conditions, is not present in the fibronectin molecule [55]. However, the EDB domain is typically inserted in the fibronectin molecules at sites of tissue remodelling by a mechanism of alternative splicing at the level of the primary transcript. The EDB domain has an identical sequence in mouse, rat, rabbit, dog, monkey and man. This sequence conservation greatly facilitates the pre-clinical and clinical development of EDB targeting agents, as it allows the same EDB binding molecule to be used in different immunocompetent syn-

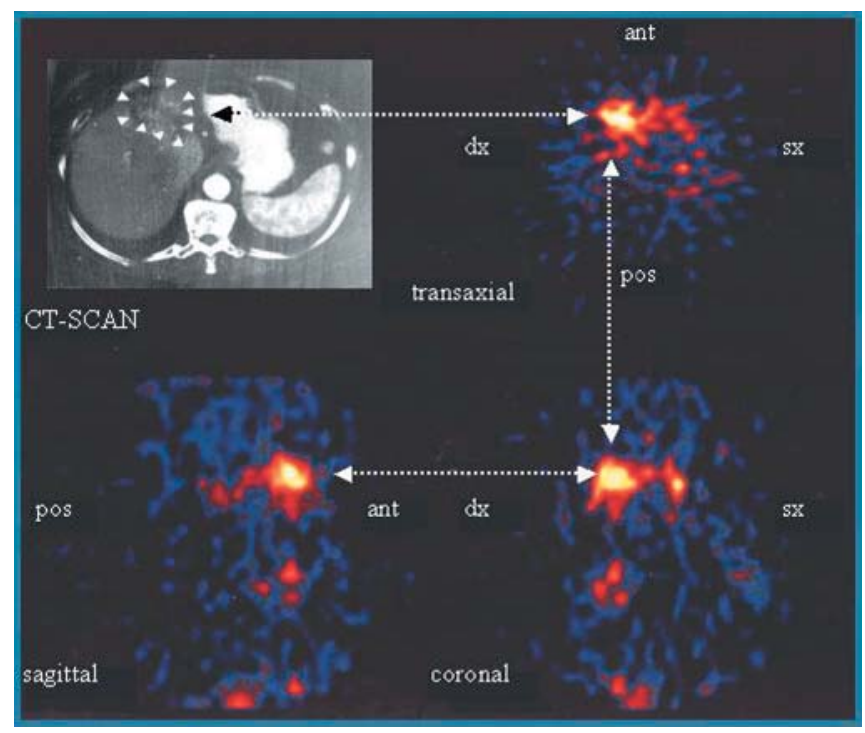

Fig. 2. SPECT images obtained $21 \mathrm{~h}$ after injection of radioiodinated $\mathrm{scFv}(\mathrm{L} 19)$, showing the transaxial, sagittal and coronal projections of the abdomen of a patient with liver metastases of colorectal cancer, were matched to the $\mathrm{CT}$ scan of the abdomen of the same patient. Adapted from [68]

geneic animal models of pathologies and in patients. Antibodies recognising a cryptic epitope on domain VII of fibronectin (which is adjacent to EDB) have been available since the late 1980s [56, 57]. However, possibly because of tolerance, the isolation of anti-EDB monoclonal antibodies using hybridoma technology has not been possible until now, and antisera to EDB have been shown to recognise EDB-containing fibronectin only after $N$-glycanase treatment [58].

Using human antibody phage technology $[59,60]$ and other recombinant antibody technologies [61], our group (in collaboration with the group of L. Zardi in Genoa) has isolated a number of human monoclonal antibodies to EDB [62-64]. In particular, $\mathrm{scFv}(\mathrm{L} 19)$ is a human antibody fragment with subnanomolar affinity to EDB [64], which has been shown to efficiently localise on tumoural and non-tumoural neovasculature both in animal models [65-67] and in patients with cancer [68]. Figure 2 shows single-photon emission computed tomography (SPECT) images from a patient with liver metastases of colorectal cancer. Selective uptake of the radiolabelled $\operatorname{scFv}(\mathrm{L} 19)$ in the lesions is clearly visible in the transaxial, coronal and sagittal projections. A careful biodistribution analysis of the L19 antibody in scFv, mini-antibody and $\mathrm{IgG}$ format has recently been reported [69].

A large number of derivatives of the L19 antibody have been produced and tested in pre-clinical animal models, including conjugates with photosensitisers [70], therapeutic radionuclides (unpublished), drugs (unpublished), liposomes [71], procoagulant agents [72], cytokines [73-77], enzymes [78] and other binding proteins $[79,80]$. 
Fig. 3. a Frozen tissue section of a human squamous cell carcinoma of the tonsils, stained with an antibody specific to a large isoform of tenascin-C ( red). Counterstaining was performed with Gill's haematoxylin.

b Frozen tissue section of a subcutaneously grown mouse F9 teratocarcinoma, stained with L19, a human antibody specific to the oncofetal fibronectin isoform (red) and counterstained with Gill's haematoxylin
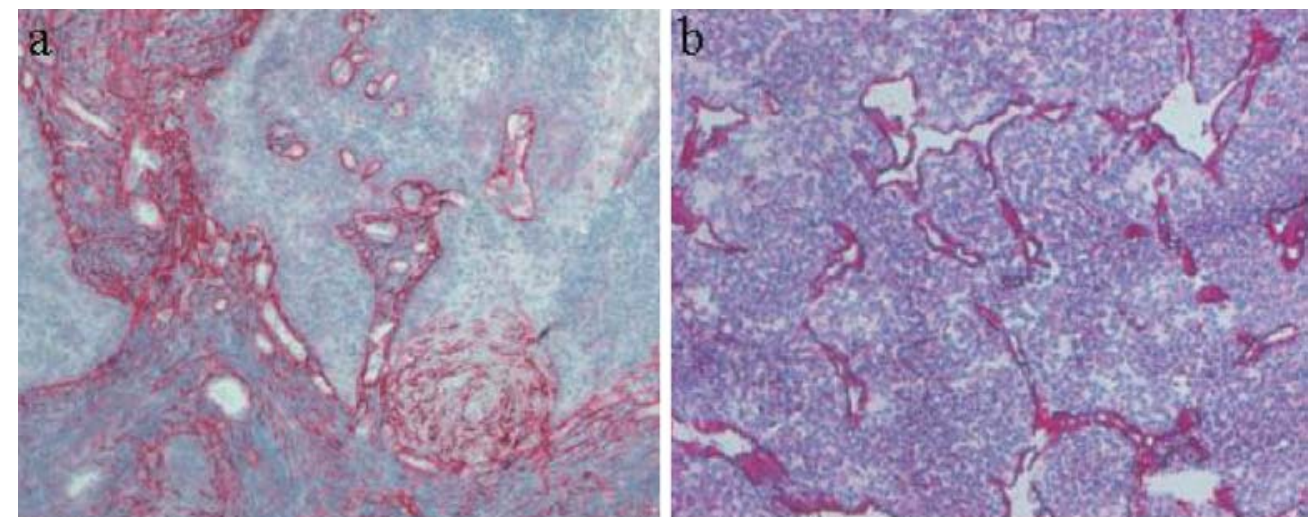

EDB is essentially undetectable in most normal adult tissues, with the notable exceptions of the endometrium in the proliferative phase and some vessels of the ovaries. However, EDB is abundantly expressed in a variety of solid tumours [56, 62, 81-85] as well as in ocular angiogenesis [70, 86], RA [87] and wound healing [88]. Typically, the pattern of EDB expression in tumours either is predominantly perivascular or exhibits a diffuse staining of the tumour stroma. In different conditions, tumour cells, fibroblasts and/or endothelial cells may contribute to the synthesis of EDB-containing fibronectin. In mice, the targeted deletion of the EDB exon resulted in transgenic mice which developed normally, healed bone fractures normally and which could develop tumours, thus suggesting that the function of EDB is redundant in mice.

\section{Large tenascin- $\mathrm{C}$ isoforms}

Several isoforms of tenascin-C can be generated as a result of alternative splicing which may lead to the inclusion of (multiple) domains in the central part of this protein, ranging from domain A1 to domain D $[89,90]$. Traditionally, one has referred to the large isoform of tenascin-C for tenascin molecules which would putatively contain all the extra domains, and to the small tenascin- $\mathrm{C}$ isoform whenever the extra domains were $\mathrm{ab}-$ sent. A strong over-expression of the large isoform of tenascin-C has been reported for a number of tumours [90], and two monoclonal antibodies specific for domains A1 and D, respectively [91-95], have been extensively characterised in the clinic.

Figure 3 shows tumour sections stained with the L19 antibody specific to EDB and with a human monoclonal antibody specific to a large isoform of tenascin-C. In both cases, tumour vascular structures are strongly stained in red.

Recently, we have reported (in collaboration with the Zardi group) that the extra domain $\mathrm{C}$ of tenascin- $\mathrm{C}$ displays a more restricted pattern of expression compared with the other extra domains of tenascin-C [96], with a predominantly perivascular staining as depicted with immunohistochemistry. The $\mathrm{C}$ domain of tenascin- $\mathrm{C}$ is undetectable in most normal adult tissues, but is over-expressed in high-grade astrocytomas [96] and other tumour types (unpublished).

Integrins $\alpha_{\mathrm{v}} \beta_{3}$ and $\alpha_{\mathrm{v}} \beta_{5}$

Integrins $\alpha_{\mathrm{v}} \beta_{3}$ and $\alpha_{\mathrm{v}} \beta_{5}$ have been proposed as markers of angiogenesis [36, 97-99] and as targets both for antibody-based inhibitory strategies and for the ligand-based delivery of therapeutics to the tumour neovasculature. While these integrins are over-expressed in several solid tumours, expression in normal tissues has been reported in immunohistochemical studies [100]. A high-affinity human monoclonal antibody to the integrin $\alpha_{v} \beta_{3}$ has been studied in an exploratory immunoscintigraphic clinical study, but yielded disappointing results for tumour imaging [101].

\section{Prostate-specific membrane antigen (PSMA)}

Prostate-specific membrane antigen (PSMA) is a membrane glycoprotein with hydrolytic activity, which is predominantly expressed in the prostate and whose concentrations have been found to be elevated in patients with prostate cancer [102]. PSMA is present in virtually every prostate cancer, and its levels are elevated in higher grade cancers, metastatic disease and hormone-refractory prostate cancer [103, 104]. The interest in vascular targeting applications of PSMA has been stimulated by the observation that PSMA is over-expressed in the neovasculature of several solid tumour types [105, 106], while expression around blood vessels in normal tissues is limited to breast, kidney, duodenum and prostate [107]. The monoclonal antibody J591 has been used in clinical immunoscintigraphy studies for the imaging of progressing hormone-independent prostate cancer [108, 109]. 
Endoglin (CD105)

Endoglin (CD105) is a TGF $\beta$ co-receptor which is overexpressed in tumour neovasculature [110, 111]. Even though recent immunohistochemical studies have shown the expression of endoglin in normal adult tissues [112, 113], monoclonal antibodies to endoglin have been used in biodistribution studies and for imaging purposes in animal models of cancer $[114,115]$.

\section{VEGF and VEGF-receptor complex}

The discovery of VEGFs (and especially VEGF-A) as prime mediators of angiogenesis has stimulated interest in the use of VEGFs, VEGF receptors and their complexes as antigens for the targeted delivery of antibody derivatives to the tumour neovasculature. The overexpression of VEGFs and VEGF receptors in tumours is well documented [116, 117]. The selective localisation of monoclonal antibodies to VEGF-A [118, 119], VEGF receptor $2[120,121]$ and VEGF-A/VEGF receptor 2 complex [122] has been documented previously. However, the targeting efficiencies reported until now have not been spectacular, probably reflecting the relatively low absolute amounts of antigen in the tumour.

CD44

The monoclonal antibody TES-23, specific to an isoform of CD44, has been associated with some of the most impressive tumour targeting performances in rodent models of cancer. Tumour values as high as $50-150 \%$ injected dose per gram $(\% \mathrm{ID} / \mathrm{g})$ have been reported as early as $1 \mathrm{~h}$ after intravenous injection [123]. CD44 is a cell surface receptor of great molecular heterogeneity, due to both alternative splicing of at least ten out of 20 exons and extensive post-translational modifications. CD44 is a ubiquitous antigen that was initially discovered as a surface antigen on T-lymphocytes and granulocytes and later implicated in various physiological and pathophysiological processes, including embryogenesis, haematopoiesis, inflammation and tumour progression. TES-23 recognises a widely distributed form of CD44 lacking variant exons, termed $\mathrm{CD} 44 \mathrm{H}$. However, the epitope was shown to include a post-translational modification which is found in an activated, tumour-associated form of CD44H [124].

CD44 splice variants which contain exon 6, CD44v6, are involved in tumour progression $[125,126]$. Antibodies specific for CD44v6 (CD44 splice variants which contain exon 6) are currently undergoing clinical trials [127].
Phosphatidyl serine phospholipids

Phosphatidyl serine phospholipids (PS) are major components of the cell membrane which, in normal conditions, are confined to the inner leaflet of the lipid bilayer. However, under conditions of cellular stress and apoptosis (and particularly in proliferating endothelial cells), the exposure of phosphatidyl serine to the outer leaflet of endothelial cell membranes (making it "visible" for targeting molecules) has been reported. Annexin V and monoclonal antibodies have been used to confirm the surface accessibility of the phosphatidyl serine moiety on endothelial cells in vitro (for example, after treatment with hydrogen peroxide) and in vivo [128]. The impressive microscopic analysis of tumour targeting performance by monoclonal antibodies to PS has not yet been complemented by a quantitative biodistribution analysis, but the 9D2 antibody displayed a potent anti-tumour activity even when used as naked antibody in rodent models of cancer.

The surface display of PS on activated platelets has been reported previously $[129,130]$, and it remains to be seen whether this property may facilitate tumour targeting applications (in view of the fact that blood coagulation often leads to the formation of a provisional extracellular matrix in solid tumours) or may hinder the selective localisation of monoclonal antibodies to tumour neovasculature.

\section{Magic roundabout (ROBO-4)}

Over the past few years, the Bicknell group has developed bioinformatic strategies that utilise the wealth of information now accessible in the public databases to identify novel endothelial-specific genes. One of the genes identified is magic roundabout (MR or ROBO-4) [131]. The roundabout family of genes comprises several closely related genes (three in man) that were previously thought to be present only in neuronal tissue and to be involved in axon guidance. Roundabouts have five $\operatorname{IgG}$ and three fibronectin-like extracellular domains. They are large transmembrane receptors for ligands known as slits (three in man). The discovery of an endothelial-specific roundabout was quite unexpected. Analysis of MR expression by a combination of Northern blotting, in situ hybridisation and immunohistochemistry has shown it to be highly restricted. Thus, MR is absent from adult tissues except at sites of active angiogenesis, including tumours. It is highly expressed in the embryo and it is presumed that it is a gene intimately involved in the development of the vasculature. This expression pattern is highly unusual and has previously been found only for delta4, an endothelial-specific member of the delta family. The pattern of MR expression makes it ideally suited to vascular targeting. The latter has been known for many years to be an effective strategy to eradicate large 
solid tumours in mouse models but its development in man has been hindered by the lack of a suitable target. Biodistribution studies with radiolabelled ligands (e.g. monoclonal antibodies) are badly needed, in order to assess the real potential of ROBO-4 as a target for imaging and/or biomolecular therapeutic intervention.

Other markers: aminopeptidase $\mathrm{N}$, annexin A1

Recent proteomic methodologies (such as in vivo peptide phage panning or silica bead-based recovery of endothelial cell proteins-see "Methodologies to discover novel markers of angiogenesis")- -have identified a vascular form of aminopeptidase N (CD13) [132] and annexin A1 [117] as markers of tumour angiogenesis, which are readily accessible from the bloodstream. For CD13 ligands, evidence of vascular targeting activity has been indirect until now, and was mainly based on immunohistochemical studies of tissue sections following intravenous injection of phage peptide [132] or on the improved anticancer therapeutic index of TNF-peptide fusion proteins compared with native TNF [133].

By contrast, impressive tumour targeting data have recently been reported for antibodies specific to rat annexin A1 in a rat lung metastasis model of breast cancer. Values of $34 \% \mathrm{ID} / \mathrm{g}$ have been reported in rat tumours as early as $2 \mathrm{~h}$ after intravenous injection of the antibody, radiolabelled with ${ }^{125} \mathrm{I}$. However, it is not clear from the article whether one or more antibodies to rat annexin A1 were used for the tumour targeting experiment. Moreover, the ${ }^{125}$ I-labelled antibody was found to be therapeutic in rats at relatively low doses (single injection of $50 \mu \mathrm{Ci}$ radiolabelled antibody per rat).

\section{Methodologies to discover novel markers of angiogenesis}

Transcriptomic analysis of tumour endothelial cells

The hypothesis that the tumour environment would trigger the over-expression of certain genes in the endothelial cells of tumour neovasculature triggered research activities in which the transcriptomic profile of endothelial cells in normal tissues and in tumours were compared. The first approaches relied on subtractive hybridisation techniques and led to the identification of $\mathrm{H}$ cadherin as a protein which was over-expressed in the neovasculature of certain tumours. The same antigen, however, was also present in the vasculature of some normal organs [134].

Shortly afterwards, St Croix and colleagues performed a genome-wide comparison of normal and tumour-derived endothelial cells using serial analysis of gene expression (SAGE) [135]. The analysis pinpointed genes (termed tumour endothelial markers, or "TEMs") which were preferentially found in tumour endothelial cells. For some of these TEMs, preferential expression in tumour endothelial cells was confirmed by in situ hybridisation. Since this seminal paper, a number of groups have worked on similar experimental approaches, improving the methodologies for endothelial cell purification and mRNA extraction, often preferring Affymetrix gene chip technology for the genome-wide comparison of transcriptomes.

As more and more transcriptomes of solid tumours and of endothelial cells have become available, researchers have started to compare these databases, with the aim of discovering endothelial cell-specific tumourassociated markers. Crossing of expression databases of well-defined in vitro cell culture models of angiogenesis with expression data from diagnostic samples of human diseased tissues, followed by further prioritisation, resulted in the identification of stanniocalcin as a putative endothelial marker of cancer [136]. In situ hybridisation analysis showed a striking over-expression of stanniocalcin in the neovasculature of colorectal cancer. The antigen was undetectable in the normal colon mucosa. However, expression of stanniocalcin in various adult organs (thyroid gland, ovary, prostate, kidney) at high levels has been reported [137], although some discrepancies in the literature about the tissue distribution of this protein have emerged [138]. The bioinformatics approach which has led to the identification of magic roundabout as a marker of tumour angiogenesis has been described in "Markers of angiogenesis for vascular targeting."

\section{Perfusion with silica beads}

In principle, the most direct way to discover novel markers of angiogenesis consists in the in vivo labelling of vascular structures, followed by recovery and comparative proteomic analysis. The group of Jan Schnitzer reported the use of colloidal silica for the in vivo coating of the vasculature $[139,140]$. The physical modification enabled the enrichment of silica-coated structures such as luminal cell plasma membranes and their caveolae. Recently, 2D-PAGE analysis of silica-coated plasma membranes from rat lungs bearing breast adenocarcinoma and from normal rat lungs led to the identification of a number of tumour-specific vascular proteins [117]. Apart from proteins which were known to be specific for the tumour vasculature (VEGF receptors, endoglin, aminopeptidase $\mathrm{N}$ and others), some proteins without a known association with the tumour vasculature have been identified, like annexin A1.

\section{In vivo biotinylation}

Our group has developed a methodology for the in vivo chemical labelling and identification of vascular proteins. 
We perform terminal perfusion of tumour-bearing mice with a reactive ester of biotin (biotin-LC-sulfoNHS from Pierce) [(Rybak et al., Proteomics, 2004, in press)]. This compound covalently modifies primary amino groups present in proteins and phospholipids. The charged sulphate moiety in the biotin derivative minimises the crossing of cell membranes, which results in a preferential labelling of cell surface proteins that are readily accessible from the bloodstream. A similar approach has previously been used in an ex vivo system by De La Fuente and colleagues [141].

Biotinylated proteins can be purified on a streptavidin column in the presence of SDS from homogenised tissue. For proteomic investigation, several methodologies can be considered, for instance 2D-PAGE, 1D-PAGE after chromatographic pre-fractionation or gel-free spectrometric analysis.

\section{Ligand-based methodologies}

Ruoslahti, Pasqualini and co-workers have pioneered the in vivo biopanning of phage peptide libraries in an attempt to identify binding specificities against different vascular addresses in different tissues and/or tumours $[142,143]$. This approach has led to the discovery of peptides specific for aminopeptidase $\mathrm{N}$ and for integrins $[132,144]$. In principle, binding specificities can be obtained against unknown vascular proteins which are accessible from the luminal side of blood vessels. Binding peptides may facilitate the identification of the cognate antigen. Even though indirect evidence of tumour targeting is available (e.g. ex vivo immunohistochemical analysis from mice injected with phage peptides), biodistribution studies with pure peptides are badly needed to demonstrate the real potential of the technology and its general applicability.

\section{Ligands for targeting applications}

\section{Antibodies}

The invention of hybridoma technology for the generation of monoclonal antibodies [3], followed by the identification of disease-associated antigens, has stimulated myriad pre-clinical and clinical studies for the imaging and/or therapy of angiogenesis-related diseases. It is now well established that rodent antibodies are immunogenic in humans.

In 1986, the group of Greg Winter pioneered the generation of humanised antibodies [145], obtained by transplanting the complementarity determining regions (CDRs) of murine antibodies onto a human antibody framework. Several humanised antibodies are now approved both in Europe and in the USA. Antibody humanisation was later complemented by the generation of human antibodies by immunisation of transgenic animals carrying human immunoglobulin genes [146, 147] and by antibody phage technology [59].

The display of antibody fragments on the surface of filamentous phage allows the easy construction of large ( $>10^{9}$ antibodies) libraries of human antibodies, from which monoclonal antibodies can be isolated by panning the phage library onto an immobilised antigen. When required, antibody affinity can be "matured" using combinatorial mutagenesis of the antibody gene and stringent selection strategies [64, 148-151]. Antibody phage technology directly yields antibody fragments (typically in $\mathrm{scFv}$ or Fab format). However, other antibody formats (e.g. IgG) can easily be obtained by transplanting the genes coding for the variable antibody domains into suitable expression vectors.

Recently, ribosome display has been proposed as a fully in vitro avenue for the isolation and affinity maturation of human antibodies [152-154].

\section{Peptides}

A number of peptides have been suggested to be capable of selective localisation on tumour neovasculature. In addition to the phage peptides identified by the groups of Ruoslahti and Pasqualini [142-144, 155], peptides resulting from the degradation of extracellular matrix components have been shown to target tumour blood vessels using microscopic techniques [156, 157]. Quantitative biodistribution studies in animals or scintigraphic studies in patients are badly needed in order to confirm these initial promising observations. Biodistribution studies in animals with integrin-binding RGD-containing peptides have so far yielded disappointing tumour/organ ratios. Novel technologies for the isolation of high-affinity binding peptides are available [158], but in vivo stability of linear peptides remains a cause of concern. On the other hand, the validated use of cyclic peptides (such as somatostatin analogues) binding to internalising receptors for tumour targeting applications suggests that such molecular structures may also be suitable for the molecular targeting of angiogenesis one day.

\section{Aptamers}

Besides antibodies, aptamers (single-stranded nucleic acids capable of adopting a complex three-dimensional structure) are possibly the only other class of molecules from which specific binding molecules against a variety of target antigens can be isolated (reviewed in [159]). Aptamer technology relies on the fact that it is possible to generate large $\left(>10^{12}\right.$ members) libraries of singlestranded nucleic acids, which can be panned for their binding to a target antigen. The nucleic acids (RNA or DNA molecules) captured in this procedure can then be 
amplified using PCR-based techniques, and used to generate single-stranded material for further cycles of panning. The stability of RNA molecules can be improved using Spiegelmer technology [160].

Promising imaging studies of rodent models of cancer with radiolabelled aptamers specific to tenascin-C have been described [161]. The potential of aptamers for tumour targeting applications is now being investigated in the clinic.

\section{Small organic drugs}

In contrast to antibody technology, the isolation of highaffinity small organic binders to protein antigens can be a difficult task, which often fails when the epitopes to be recognised do not contain hydrophobic pockets [162]. An increasing amount of experimental evidence suggests that bidentate ligands, recognising adjacent but nonoverlapping surfaces of the target protein, may display high binding affinity and specificity as a result of the chelate effect [163]. Methods for the identification of such bidentate ligands include "SAR by NMR" (whereby structure-activity relationships are obtained from nuclear magnetic resonance [164]), dynamic combinatorial chemistry [165] and tethering approaches [166]. We have developed encoded self-assembling chemical library technology (ESACHEL) as an avenue for the construction of large DNA-coded libraries of bidentate compounds [167]. ESACHEL libraries are generated by the stable self-assembly of pharmacophores, forming higher order structures (dimers, trimers or tetramers). In a typical implementation, organic molecules are linked to individual oligonucleotides, which mediate the self-assembly of the library and provide a code associated to each binding moiety. The resulting library can be very large, as it originates by the combinatorial self-assembly of smaller sub-libraries. After the capture of the desired binding specificities on the target of interest, the "binding code" can be "decoded" by a number of experimental techniques (e.g. hybridisation on DNA chips, by a modified PCR technique followed by sequencing). We have described the isolation of ESACHEL-derived bidentate molecules with nanomolar affinity to carbonic anhydrase II [167]. A number of carbonic anhydrases are over-expressed at sites of hypoxia in physiological and pathological conditions [168-170].

\section{Concluding remarks}

Interest in the study of pathological angiogenesis has grown steadily in the last three decades. The recognition that angiogenesis supports the development and maintenance of a wide range of serious diseases, together with the accessibility of markers of angiogenesis for pharmaceutical agents in the bloodstream, has stimulated re- search activities both for the identification of angiogenesis-associated antigens and for the development of specific binding molecules (antibodies, aptamers, peptides, etc.). The molecular targeting of angiogenesis is now recognised as a pharmaceutical strategy with considerable potential for the imaging and therapy of cancer and other angiogenesis-related diseases. However, only a small number of antigens have been subjected to a sufficiently detailed analysis in terms of immunohistochemical characterisation and biodistribution studies using well-characterised binding molecules (e.g. high-affinity antibodies). An even smaller fraction of ligands have entered clinical development programmes, making it difficult to evaluate the potential biomedical value of the cognate antigen. A more efficient translation of diagnostic and therapeutic approaches from the bench to the clinic will continue to be one of the main challenges in biomedical research in the coming years.

Our experience with monoclonal antibodies to the EDB domain of fibronectin has convinced us of the relevance of using (whenever possible) specific binding molecules capable of antigen recognition in different animal species. This cross-reactivity allows a careful evaluation of targeting agents, which are specific for markers of angiogenesis, in a syngeneic setting and immunocompetent animals, thereby offering more powerful prediction of the challenges and opportunities for clinical development activities.

In the past, monoclonal antibodies have been the sole class of binding molecules which could be generated against a wide variety of antigens, and they have therefore dominated research activities aimed at the selective delivery of bioactive molecules to sites of angiogenesis. However, the emergence of novel technologies (aptamers, encoded self-assembling chemical libraries, etc.) suggests that in the not too distant future it will be possible to perform targeting experiments with a variety of molecular agents. Perhaps we will then be able to assess the relative merits of different targeting technologies, as well as the relative value of different classes of molecules for the imaging and therapy of angiogenesisrelated diseases.

Evaluation of the biomedical potential of markers of angiogenesis located on either the luminal or the abluminal aspect of new blood vessels represents one of the most controversial areas in pathological angiogenesis research. While in the past most of the best-studied antigens have been components of the modified extracellular matrix, modern technologies such as silica bead perfusion or in vivo biotinylation allow the identification of accessible markers of angiogenesis located in the luminal aspect of new blood vessels. Quantitative biodistribution studies with well-characterised binding molecules (e.g. antibodies) are urgently needed to shed light on the pharmaceutical potential of these classes of antigen. 


\section{References}

1. Bosslet K, Straub R, Blumrich M, et al. Elucidation of the mechanism enabling tumor selective prodrug monotherapy. Cancer Res 1998; 58:1195-201.

2. Jain RK. Delivery of molecular and cellular medicine to solid tumors. Adv Drug Deliv Rev 2001;46:149-68.

3. Kohler G, Milstein C. Continuous cultures of fused cells secreting antibody of predefined specificity. Nature 1975; 256:495-7.

4. Bischoff J. Approaches to studying cell adhesion molecules in angiogenesis. Trends Cell Biol 1995; 5:69-74.

5. Folkman J. Angiogenesis in cancer, vascular, rheumatoid and other disease. Nat Med 1995; 1:27-31.

6. Pugh CW, Ratcliffe PJ. Regulation of angiogenesis by hypoxia: role of the HIF system. Nat Med 2003;9:677-84.

7. Carmeliet P. Angiogenesis in health and disease. Nat Med 2003; 9:653-60.

8. Ferrara N, Gerber HP, LeCouter J. The biology of VEGF and its receptors. Nat Med 2003; 9:669-76.

9. Hurwitz H, Fehrenbacher L, Novotny W, et al. Bevacizumab plus irinotecan, fluorouracil, and leucovorin for metastatic colorectal cancer. N Engl J Med 2004; 350:2335-42.

10. Cobleigh MA, Langmuir VK, Sledge GW, et al. A phase I/II dose-escalation trial of bevacizumab in previously treated metastatic breast cancer. Semin Oncol 2003; 30:117-24.

11. Brekke OH, Sandlie I. Therapeutic antibodies for human diseases at the dawn of the twenty-first century. Nat Rev Drug Discov 2003; 2:52-62.

12. Hudson PJ, Souriau C. Engineered antibodies. Nat Med 2003; 9:129-34.

13. Folkman J. Tumor angiogenesis: therapeutic implications. $\mathrm{N}$ Engl J Med 1971; 285:1182-6.

14. Folkman J. Anti-angiogenesis: new concept for therapy of solid tumors. Ann Surg 1972;175:409-16.

15. Hanahan D. A flanking attack on cancer. Nat Med 1998; 4:13-4.

16. Bergers G, Benjamin LE. Tumorigenesis and the angiogenic switch. Nat Rev Cancer 2003; 3:401-10.

17. Forsythe JA, Jiang BH, Iyer NV, et al. Activation of vascular endothelial growth factor gene transcription by hypoxia-inducible factor 1. Mol Cell Biol 1996; 16:4604-13.

18. Jaakkola P, Mole DR, Tian YM, et al. Targeting of HIF-alpha to the von Hippel-Lindau ubiquitylation complex by $\mathrm{O}_{2}$-regulated prolyl hydroxylation. Science 2001; 292:468-72.

19. Ivan M, Kondo K, Yang H, et al. HIFalpha targeted for VHLmediated destruction by proline hydroxylation: implications for $\mathrm{O}_{2}$ sensing. Science $2001 ; 292: 464-8$.

20. Dibbens JA, Miller DL, Damert A, et al. Hypoxic regulation of vascular endothelial growth factor mRNA stability requires the cooperation of multiple RNA elements. Mol Biol Cell 1999; 10:907-19.

21. Tenan M, Fulci G, Albertoni M, et al. Thrombospondin-1 is downregulated by anoxia and suppresses tumorigenicity of human glioblastoma cells. J Exp Med 2000; 191:1789-98.

22. Konerding MA, Fait E, Gaumann A. 3D microvascular architecture of pre-cancerous lesions and invasive carcinomas of the colon. Br J Cancer 2001; 84:1354-62.

23. Roberts WG, Palade GE. Neovasculature induced by vascular endothelial growth factor is fenestrated. Cancer Res 1997; 57:765-72.

24. Jain RK. Transport of molecules across tumor vasculature. Cancer Metastasis Rev 1987; 6:559-93.
25. Hashizume H, Baluk P, Morikawa S, et al. Openings between defective endothelial cells explain tumor vessel leakiness. Am J Pathol 2000; 156:1363-80.

26. Ferrara N, Hillan KJ, Gerber HP, Novotny W. Discovery and development of bevacizumab, an anti-VEGF antibody for treating cancer. Nat Rev Drug Discov 2004; 3:391-400.

27. Lee P, Wang CC, Adamis AP. Ocular neovascularization: an epidemiologic review. Surv Ophthalmol 1998; 43:245-69.

28. Ishida S, Yamashiro K, Usui T, et al. Leukocytes mediate retinal vascular remodeling during development and vaso-obliteration in disease. Nat Med 2003; 9:781-8.

29. McLeod DS, Lefer DJ, Merges C, Lutty GA. Enhanced expression of intracellular adhesion molecule-1 and P-selectin in the diabetic human retina and choroid. Am J Pathol 1995; 147:642-53.

30. Diacovo TG, Puri KD, Warnock RA, Springer TA, von Andrian UH. Platelet-mediated lymphocyte delivery to high endothelial venules. Science 1996; 273:252-5.

31. Malecaze F, Clamens S, Simorre-Pinatel V, et al. Detection of vascular endothelial growth factor messenger RNA and vascular endothelial growth factor-like activity in proliferative diabetic retinopathy. Arch Ophthalmol 1994; 112:147682.

32. Miller JW, Adamis AP, Shima DT, et al. Vascular endothelial growth factor/vascular permeability factor is temporally and spatially correlated with ocular angiogenesis in a primate model. Am J Pathol 1994; 145:574-84.

33. Dawson DW, Volpert OV, Gillis P, et al. Pigment epitheliumderived factor: a potent inhibitor of angiogenesis. Science 1999; 285:245-8.

34. Ogata N, Nishikawa M, Nishimura T, Mitsuma Y, Matsumura M. Unbalanced vitreous levels of pigment epithelium-derived factor and vascular endothelial growth factor in diabetic retinopathy. Am J Ophthalmol 2002; 134:348-53.

35. Aiello LP, Pierce EA, Foley ED, et al. Suppression of retinal neovascularization in vivo by inhibition of vascular endothelial growth factor (VEGF) using soluble VEGF-receptor chimeric proteins. Proc Natl Acad Sci U S A 1995; 92:10457-61.

36. Friedlander M, Theesfeld CL, Sugita M, et al. Involvement of integrins alpha v beta 3 and alpha v beta 5 in ocular neovascular diseases. Proc Natl Acad Sci U S A 1996; 93:9764-9.

37. Greaves MW, Weinstein GD. Treatment of psoriasis. N Engl J Med 1995; 332:581-8.

38. Creamer D, Sullivan D, Bicknell R, Barker J. Angiogenesis in psoriasis. Angiogenesis 2002; 5:231-6.

39. Detmar M, Brown LF, Claffey KP, et al. Overexpression of vascular permeability factor/vascular endothelial growth factor and its receptors in psoriasis. J Exp Med 1994; 180:1141-6.

40. Nickoloff BJ, Mitra RS, Varani J, Dixit VM, Polverini PJ. Aberrant production of interleukin- 8 and thrombospondin-1 by psoriatic keratinocytes mediates angiogenesis. Am J Pathol 1994; $144: 820-8$.

41. Detmar M. The role of VEGF and thrombospondins in skin angiogenesis. J Dermatol Sci 2000; 24(Suppl 1):S78-84.

42. Creamer D, Allen M, Sousa A, Poston R, Barker J. Altered vascular endothelium integrin expression in psoriasis. Am J Pathol 1995; 147:1661-7.

43. Kuroda K, Sapadin A, Shoji T, Fleischmajer R, Lebwohl M. Altered expression of angiopoietins and Tie2 endothelium receptor in psoriasis. J Invest Dermatol 2001; 116:713-20.

44. Elder JT, Fisher GJ, Lindquist PB, et al. Overexpression of transforming growth factor alpha in psoriatic epidermis. Science $1989 ; 243: 811-4$. 
45. Villadsen LS, Schuurman J, Beurskens F, et al. Resolution of psoriasis upon blockade of IL-15 biological activity in a xenograft mouse model. J Clin Invest 2003; 112:1571-80.

46. Folkman J. Angiogenesis in psoriasis: therapeutic implications. J Invest Dermatol 1972; 59:40-3.

47. Hernandez GL, Volpert OV, Iniguez MA, et al. Selective inhibition of vascular endothelial growth factor-mediated angiogenesis by cyclosporin A: roles of the nuclear factor of activated T cells and cyclooxygenase 2. J Exp Med 2001; 193:607-20.

48. Diaz BV, Lenoir MC, Ladoux A, et al. Regulation of vascular endothelial growth factor expression in human keratinocytes by retinoids. J Biol Chem 2000; 275:642-50.

49. Ballara S, Taylor PC, Reusch P, et al. Raised serum vascular endothelial growth factor levels are associated with destructive change in inflammatory arthritis. Arthritis Rheum 2001; 44:2055-64.

50. Grosios K, Wood J, Esser R, Raychaudhuri A, Dawson J. Angiogenesis inhibition by the novel VEGF receptor tyrosine kinase inhibitor, PTK787/ZK222584, causes significant antiarthritic effects in models of rheumatoid arthritis. Inflamm Res 2004; 53:133-42.

51. Szekanecz Z, Szegedi G, Koch AE. Angiogenesis in rheumatoid arthritis: pathogenic and clinical significance. J Investig Med 1998; 46:27-41.

52. Koch AE. Review: angiogenesis: implications for rheumatoid arthritis. Arthritis Rheum 1998; 41:951-62.

53. Maini RN, Taylor PC. Anti-cytokine therapy for rheumatoid arthritis. Annu Rev Med 2000; 51:207-29.

54. Feldmann M, Brennan FM, Paleolog E, et al. Anti-TNFalpha therapy of rheumatoid arthritis: what can we learn about chronic disease? Novartis Found Symp 2000; 256:53-69; discussion 69-73, 106-111, 266-9.

55. Zardi L, Carnemolla B, Siri A, et al. Transformed human cells produce a new fibronectin isoform by preferential alternative splicing of a previously unobserved exon. EMBO J 1987; 6:2337-42.

56. Carnemolla B, Balza E, Siri A, et al. A tumor-associated fibronectin isoform generated by alternative splicing of messenger RNA precursors. J Cell Biol 1989; 108:1139-48.

57. Carnemolla B, Leprini A, Allemanni G, Saginati M, Zardi L. The inclusion of the type III repeat ED-B in the fibronectin molecule generates conformational modifications that unmask a cryptic sequence. J Biol Chem 1992; 267:2468992.

58. Peters JH, Trevithick JE, Johnson P, Hynes RO. Expression of the alternatively spliced EIIIB segment of fibronectin. Cell Adhes Commun 1995; 3:67-89.

59. Winter G, Griffiths AD, Hawkins RE, Hoogenboom HR. Making antibodies by phage display technology. Annu Rev Immunol 1994; 12:433-55.

60. Viti F, Nilsson F, Demartis S, Huber A, Neri D. Design and use of phage display libraries for the selection of antibodies and enzymes. Methods Enzymol 2000; 326:480-505.

61. Giovannoni L, Viti F, Zardi L, Neri D. Isolation of anti-angiogenesis antibodies from a large combinatorial repertoire by colony filter screening. Nucleic Acids Res 2001;29:E27.

62. Carnemolla B, Neri D, Castellani P, et al. Phage antibodies with pan-species recognition of the oncofoetal angiogenesis marker fibronectin ED-B domain. Int J Cancer 1996; 68:397-405.

63. Neri D, Carnemolla B, Nissim A, et al. Targeting by affinitymatured recombinant antibody fragments of an angiogenesis associated fibronectin isoform. Nat Biotechnol 1997; 15:1271-5.

64. Pini A, Viti F, Santucci A, et al. Design and use of a phage display library. Human antibodies with subnanomolar affinity against a marker of angiogenesis eluted from a two-dimensional gel. J Biol Chem 1998; 273:21769-76.

65. Viti F, Tarli L, Giovannoni L, Zardi L, Neri D. Increased binding affinity and valence of recombinant antibody fragments lead to improved targeting of tumoral angiogenesis. Cancer Res 1999; 59:347-52.

66. Tarli L, Balza E, Viti F, et al. A high-affinity human antibody that targets tumoral blood vessels. Blood 1999; 94:192-8.

67. Demartis S, Tarli L, Borsi L, Zardi L, Neri D. Selective targeting of tumour neovasculature by a radiohalogenated human antibody fragment specific for the ED-B domain of fibronectin. Eur J Nucl Med 2001; 28:534-9.

68. Santimaria M, Moscatelli G, Viale GL, et al. Immunoscintigraphic detection of the ED-B domain of fibronectin, a marker of angiogenesis, in patients with cancer. Clin Cancer Res 2003; 9:571-9.

69. Borsi L, Balza E, Bestagno M, et al. Selective targeting of tumoral vasculature: comparison of different formats of an antibody (L19) to the ED-B domain of fibronectin. Int J Cancer 2002; 102:75-85.

70. Birchler M, Viti F, Zardi L, Spiess B, Neri D. Selective targeting and photocoagulation of ocular angiogenesis mediated by a phage-derived human antibody fragment. Nat Biotechnol 1999; 17:984-88.

71. Marty C, Odermatt B, Schott H, et al. Cytotoxic targeting of F9 teratocarcinoma tumours with anti-ED-B fibronectin scFv antibody modified liposomes. Br J Cancer 2002; 87:106-12.

72. Nilsson F, Kosmehl H, Zardi L, Neri D. Targeted delivery of tissue factor to the ED-B domain of fibronectin, a marker of angiogenesis, mediates the infarction of solid tumors in mice. Cancer Res 2001; 61:711-6.

73. Carnemolla B, Borsi L, Balza E, et al. Enhancement of the antitumor properties of interleukin- 2 by its targeted delivery to the tumor blood vessel extracellular matrix. Blood 2002; 99:1659-65.

74. Halin C, Niesner U, Villani ME, Zardi L, Neri D. Tumor-targeting properties of antibody-vascular endothelial growth factor fusion proteins. Int J Cancer 2002; 102:109-16.

75. Halin C, Rondini S, Nilsson F, et al. Enhancement of the antitumor activity of interleukin-12 by targeted delivery to neovasculature. Nat Biotechnol 2002; 20:264-9.

76. Borsi L, Balza E, Carnemolla B, et al. Selective targeted delivery of TNFalpha to tumor blood vessels. Blood 2003; 102:4384-92.

77. Halin C, Gafner V, Villani ME, et al. Synergistic therapeutic effects of a tumor targeting antibody fragment, fused to interleukin 12 and to tumor necrosis factor alpha. Cancer Res 2003; 63:3202-10.

78. Heinis C, Alessi P, Neri D. Engineering a thermostable human prolyl endopeptidase for antibody-directed enzyme prodrug therapy. Biochemistry 2004;43:6293-303.

79. Niesner U, Halin C, Lozzi L, et al. Quantitation of the tumortargeting properties of antibody fragments conjugated to cellpermeating HIV-1 TAT peptides. Bioconjug Chem 2002; 13:729-36.

80. Melkko S, Halin C, Borsi L, Zardi L, Neri D. An antibodycalmodulin fusion protein reveals a functional dependence between macromolecular isoelectric point and tumor targeting performance. Int J Radiat Oncol Biol Phys 2002; 54:1485-90. 
81. Castellani P, Viale G, Dorcaratto A, et al. The fibronectin isoform containing the ED-B oncofetal domain: a marker of angiogenesis. Int J Cancer 1994; 59:612-8.

82. Kaczmarek J, Castellani P, Nicolo G, et al. Distribution of oncofetal fibronectin isoforms in normal, hyperplastic and neoplastic human breast tissues. Int J Cancer 1994; 59:11-6.

83. Castellani P, Borsi L, Carnemolla B, et al. Differentiation between high- and low-grade astrocytoma using a human recombinant antibody to the extra domain-B of fibronectin. Am J Pathol 2002; 161:1695-700.

84. Birchler MT, Milisavlijevic D, Pfaltz M, et al. Expression of the extra domain B of fibronectin, a marker of angiogenesis, in head and neck tumors. Laryngoscope 2003; 113:1231-7.

85. Kosmehl H, Berndt A, Strassburger S, et al. Distribution of laminin and fibronectin isoforms in oral mucosa and oral squamous cell carcinoma. Br J Cancer 1999; 81:1071-9.

86. Nicolo M, Biro A, Cardillo-Piccolino F, et al. Expression of extradomain-B-containing fibronectin in subretinal choroidal neovascular membranes. Am J Ophthalmol 2003; 135:713.

87. Kriegsmann J, Berndt A, Hansen T, et al. Expression of fibronectin splice variants and oncofetal glycosylated fibronectin in the synovial membranes of patients with rheumatoid arthritis and osteoarthritis. Rheumatol Int 2004; 24:25-33.

88. Ffrench-Constant C, Van de Water L, Dvorak HF, Hynes RO. Reappearance of an embryonic pattern of fibronectin splicing during wound healing in the adult rat. J Cell Biol 1989; 109:903-14.

89. Carnemolla B, Borsi L, Bannikov G, Troyanovsky S, Zardi L. Comparison of human tenascin expression in normal, simian-virus-40-transformed and tumor-derived cell lines. Eur J Biochem 1992; 205:561-7.

90. Borsi L, Carnemolla B, Nicolo G, et al. Expression of different tenascin isoforms in normal, hyperplastic and neoplastic human breast tissues. Int J Cancer 1992; 52:688-92.

91. Paganelli G, Magnani P, Zito F, et al. Pre-targeted immunodetection in glioma patients: tumour localization and singlephoton emission tomography imaging of $\left[{ }^{99 \mathrm{~m}} \mathrm{Tc}\right] \mathrm{PnAO}-\mathrm{bi}-$ otin. Eur J Nucl Med 1994; 21:314-21.

92. Riva P, Arista A, Franceschi G, et al. Local treatment of malignant gliomas by direct infusion of specific monoclonal antibodies labeled with ${ }^{131} \mathrm{I}$ : comparison of the results obtained in recurrent and newly diagnosed tumors. Cancer Res 1995; 55:5952s-6s.

93. Riva P, Arista A, Sturiale C, et al. Treatment of intracranial human glioblastoma by direct intratumoral administration of ${ }^{131} \mathrm{I}$-labelled anti-tenascin monoclonal antibody BC-2. Int J Cancer 1992; 51:7-13.

94. Reardon DA, Akabani G, Coleman RE, et al. Phase II trial of murine ${ }^{131} \mathrm{I}$-labeled antitenascin monoclonal antibody $81 \mathrm{C} 6$ administered into surgically created resection cavities of patients with newly diagnosed malignant gliomas. J Clin Oncol 2002; 20:1389-97.

95. Bigner DD, Brown MT, Friedman AH, et al. Iodine-131-labeled antitenascin monoclonal antibody 81C6 treatment of patients with recurrent malignant gliomas: phase I trial results. J Clin Oncol 1998; 16:2202-12.

96. Carnemolla B, Castellani P, Ponassi M, et al. Identification of a glioblastoma-associated tenascin- $\mathrm{C}$ isoform by a high affinity recombinant antibody. Am J Pathol 1999; 154:1345-52.

97. Friedlander M, Brooks PC, Shaffer RW, et al. Definition of two angiogenic pathways by distinct alpha $\mathrm{v}$ integrins. Science $1995 ; 270: 1500-2$.
98. Sipkins DA, Cheresh DA, Kazemi MR, et al. Detection of tumor angiogenesis in vivo by alphaVbeta3-targeted magnetic resonance imaging. Nat Med 1998; 4:623-6.

99. Brooks PC, Montgomery AM, Rosenfeld M, et al. Integrin alpha $\mathrm{v}$ beta 3 antagonists promote tumor regression by inducing apoptosis of angiogenic blood vessels. Cell 1994; 79:1157-64.

100. Max R, Gerritsen RR, Nooijen PT, et al. Immunohistochemical analysis of integrin alpha vbeta3 expression on tumor-associated vessels of human carcinomas. Int J Cancer 1997; 71:320-4.

101. Posey JA, Khazaeli MB, DelGrosso A, et al. A pilot trial of Vitaxin, a humanized anti-vitronectin receptor (anti alpha $\mathrm{v}$ beta 3) antibody in patients with metastatic cancer. Cancer Biother Radiopharm 2001; 16:125-32.

102. Horoszewicz JS, Kawinski E, Murphy GP. Monoclonal antibodies to a new antigenic marker in epithelial prostatic cells and serum of prostatic cancer patients. Anticancer Res 1987; 7:927-35.

103. Wright GL Jr, Grob BM, Haley C, et al. Upregulation of prostate-specific membrane antigen after androgen-deprivation therapy. Urology 1996; 48:326-34.

104. Xiao Z, Adam BL, Cazares LH, et al. Quantitation of serum prostate-specific membrane antigen by a novel protein biochip immunoassay discriminates benign from malignant prostate disease. Cancer Res 2001; 61:6029-33.

105. Liu H, Moy P, Kim S, et al. Monoclonal antibodies to the extracellular domain of prostate-specific membrane antigen also react with tumor vascular endothelium. Cancer Res 1997; 57:3629-34.

106. Chang SS, O'Keefe DS, Bacich DJ, et al. Prostate-specific membrane antigen is produced in tumor-associated neovasculature. Clin Cancer Res 1999; 5:2674-81.

107. Chang SS, Reuter VE, Heston WD, et al. Five different antiprostate-specific membrane antigen (PSMA) antibodies confirm PSMA expression in tumor-associated neovasculature. Cancer Res 1999; 59:3192-8.

108. Bander NH, Trabulsi EJ, Kostakoglu L, et al. Targeting metastatic prostate cancer with radiolabeled monoclonal antibody J591 to the extracellular domain of prostate specific membrane antigen. J Urol 2003; 170:1717-21.

109. Bander NH, Nanus DM, Milowsky MI, et al. Targeted systemic therapy of prostate cancer with a monoclonal antibody to prostate-specific membrane antigen. Semin Oncol 2003; 30:667-76.

110. Wang JM, Kumar S, Pye D, et al. A monoclonal antibody detects heterogeneity in vascular endothelium of tumours and normal tissues. Int J Cancer 1993; 54:363-70.

111. Burrows FJ, Derbyshire EJ, Tazzari PL, et al. Up-regulation of endoglin on vascular endothelial cells in human solid tumors: implications for diagnosis and therapy. Clin Cancer Res 1995; 1:1623-34.

112. Balza E, Castellani P, Zijlstra A, et al. Lack of specificity of endoglin expression for tumor blood vessels. Int $\mathrm{J}$ Cancer 2001; 94:579-85.

113. Matsubara S, Bourdeau A, terBrugge KG, Wallace C, Letarte M. Analysis of endoglin expression in normal brain tissue and in cerebral arteriovenous malformations. Stroke 2000; 31:2653-60.

114. Bredow S, Lewin M, Hofmann B, Marecos E, Weissleder R. Imaging of tumour neovasculature by targeting the TGFbeta binding receptor endoglin. Eur J Cancer 2000; 36:67581. 
115. Fonsatti E, Jekunen AP, Kairemo KJ, et al. Endoglin is a suitable target for efficient imaging of solid tumors: in vivo evidence in a canine mammary carcinoma model. Clin Cancer Res 2000; 6:2037-43.

116. Brekken RA, Huang X, King SW, Thorpe PE. Vascular endothelial growth factor as a marker of tumor endothelium. Cancer Res 1998; 58:1952-59.

117. Oh P, Li Y, Yu J, et al. Subtractive proteomic mapping of the endothelial surface in lung and solid tumours for tissue-specific therapy. Nature 2004; 429:629-35.

118. Cooke SP, Boxer GM, Lawrence L, et al. A strategy for antitumor vascular therapy by targeting the vascular endothelial growth factor: receptor complex. Cancer Res 2001; 61:3653-9.

119. Ke L, Qu H, Nagy JA, et al. Vascular targeting of solid and ascites tumours with antibodies to vascular endothelial growth factor. Eur J Cancer 1996; 32A:2467-73.

120. Prewett M, Huber J, Li Y, et al. Antivascular endothelial growth factor receptor (fetal liver kinase 1) monoclonal antibody inhibits tumor angiogenesis and growth of several mouse and human tumors. Cancer Res 1999; 59:5209-18.

121. Zhu Z, Witte L. Inhibition of tumor growth and metastasis by targeting tumor-associated angiogenesis with antagonists to the receptors of vascular endothelial growth factor. Invest New Drugs 1999; 17:195-212.

122. Brekken RA, Overholser JP, Stastny VA, et al. Selective inhibition of vascular endothelial growth factor (VEGF) receptor 2 (KDR/Flk-1) activity by a monoclonal anti-VEGF antibody blocks tumor growth in mice. Cancer Res 2000; 60:5117-24.

123. Wakai Y, Matsui J, Koizumi K, et al. Effective cancer targeting using an anti-tumor tissue vascular endothelium-specific monoclonal antibody (TES-23). Jpn J Cancer Res 2000; 91:1319-25.

124. Taniguchi K, Harada N, Ohizumi I, et al. Recognition of human activated CD44 by tumor vasculature-targeted antibody. Biochem Biophys Res Commun 2000; 269:671-5.

125. Wielenga VJ, Heider KH, Offerhaus GJ, et al. Expression of CD44 variant proteins in human colorectal cancer is related to tumor progression. Cancer Res 1993; 53:4754-6.

126. Heider KH, Kuthan H, Stehle G, Munzert G. CD44v6: a target for antibody-based cancer therapy. Cancer Immunol Immunother 2004; 53:567-79.

127. Borjesson PK, Postema EJ, Roos JC, et al. Phase I therapy study with ${ }^{186}$ Re-labeled humanized monoclonal antibody BIWA 4 (bivatuzumab) in patients with head and neck squamous cell carcinoma. Clin Cancer Res 2003; 9:3961S-72S.

128. Ran S, Downes A, Thorpe PE. Increased exposure of anionic phospholipids on the surface of tumor blood vessels. Cancer Res 2002; 62:6132-40.

129. Bucki R, Janmey PA, Vegners R, Giraud F, Sulpice JC. Involvement of phosphatidylinositol 4,5-bisphosphate in phosphatidylserine exposure in platelets: use of a permeant phosphoinositide-binding peptide. Biochemistry 2001; 40:15752-61.

130. Monroe DM, Hoffman M, Roberts HR. Platelets and thrombin generation. Arterioscler Thromb Vasc Biol 2002; 22:1381-9.

131. Huminiecki L, Gorn M, Suchting S, Poulsom R, Bicknell R. Magic roundabout is a new member of the roundabout receptor family that is endothelial specific and expressed at sites of active angiogenesis. Genomics 2002; 79:547-52.

132. Pasqualini R, Koivunen E, Kain R, et al. Aminopeptidase N is a receptor for tumor-homing peptides and a target for inhibiting angiogenesis. Cancer Res 2000; 60:722-7.

133. Curnis F, Sacchi A, Borgna L, et al. Enhancement of tumor necrosis factor alpha antitumor immunotherapeutic proper- ties by targeted delivery to aminopeptidase N (CD13). Nat Biotechnol 2000; 18:1185-90.

134. Wyder L, Vitaliti A, Schneider H, et al. Increased expression of H/T-cadherin in tumor-penetrating blood vessels. Cancer Res 2000; 60:4682-8.

135. St Croix B, Rago C, Velculescu V, et al. Genes expressed in human tumor endothelium. Science 2000; 289:1197-202.

136. Gerritsen ME, Soriano R, Yang S, et al. In silico data filtering to identify new angiogenesis targets from a large in vitro gene profiling data set. Physiol Genomics 2002; 10:13-20.

137. Chang AC, Jellinek DA, Reddel RR. Mammalian stanniocalcins and cancer. Endocr Relat Cancer 2003; 10:359-73.

138. Ishibashi K, Imai M. Prospect of a stanniocalcin endocrine/paracrine system in mammals. Am J Physiol Renal Physiol 2002; 282:F367-75.

139. Jacobson BS, Schnitzer JE, McCaffery M, Palade GE. Isolation and partial characterization of the luminal plasmalemma of microvascular endothelium from rat lungs. Eur J Cell Biol 1992; 58:296-306.

140. Czarny M, Liu J, Oh P, Schnitzer JE. Transient mechanoactivation of neutral sphingomyelinase in caveolae to generate ceramide. J Biol Chem 2003; 278:4424-30.

141. De La Fuente EK, Dawson CA, Nelin LD, et al. Biotinylation of membrane proteins accessible via the pulmonary circulation in normal and hyperoxic rats. Am J Physiol 1997; 272:L461-70.

142. Pasqualini R, Ruoslahti E. Organ targeting in vivo using phage display peptide libraries. Nature 1996; 380:364-6.

143. Rajotte D, Arap W, Hagedorn M, et al. Molecular heterogeneity of the vascular endothelium revealed by in vivo phage display. J Clin Invest 1998; 102:430-7.

144. Pasqualini R, Koivunen E, Ruoslahti E. Alpha v integrins as receptors for tumor targeting by circulating ligands. Nat Biotechnol 1997; 15:542-6.

145. Jones PT, Dear PH, Foote J, Neuberger MS, Winter G. Replacing the complementarity-determining regions in a human antibody with those from a mouse. Nature 1986;321:522-5.

146. Lonberg N, Taylor LD, Harding FA, et al. Antigen-specific human antibodies from mice comprising four distinct genetic modifications. Nature 1994; 368:856-9.

147. Kellermann SA, Green LL. Antibody discovery: the use of transgenic mice to generate human monoclonal antibodies for therapeutics. Curr Opin Biotechnol 2002; 13:593-7.

148. Yang WP, Green K, Pinz-Sweeney S, et al. CDR walking mutagenesis for the affinity maturation of a potent human anti-HIV-1 antibody into the picomolar range. J Mol Biol 1995; 254:392-403.

149. Low NM, Holliger PH, Winter G. Mimicking somatic hypermutation: affinity maturation of antibodies displayed on bacteriophage using a bacterial mutator strain. J Mol Biol 1996; 260:359-68.

150. Schier R, Bye J, Apell G, et al. Isolation of high-affinity monomeric human anti-c-erbB-2 single chain Fv using affinitydriven selection. J Mol Biol 1996; 255:28-43.

151. Graff CP, Chester K, Begent R, Wittrup KD. Directed evolution of an anti-carcinoembryonic antigen $\mathrm{scFv}$ with a fourday monovalent dissociation half-time at $37^{\circ} \mathrm{C}$. Protein Eng Des Sel 2004, Apr 28 [Epub ahead of print].

152. Hanes J, Pluckthun A. In vitro selection and evolution of functional proteins by using ribosome display. Proc Natl Acad Sci U S A 1997; 94:4937-42.

153. Hanes J, Schaffitzel C, Knappik A, Pluckthun A. Picomolar affinity antibodies from a fully synthetic naive library select- 
ed and evolved by ribosome display. Nat Biotechnol 2000; 18:1287-92.

154. Lowe D, Jermutus L. Combinatorial protein biochemistry for therapeutics and proteomics. Curr Pharm Biotechnol 2004; 5:17-27.

155. Arap W, Pasqualini R, Ruoslahti E. Cancer treatment by targeted drug delivery to tumor vasculature in a mouse model. Science 1998; 279:377-80.

156. Maeshima Y, Sudhakar A, Lively JC, et al. Tumstatin, an endothelial cell-specific inhibitor of protein synthesis. Science 2002; 295:140-3.

157. Hamano Y, Zeisberg M, Sugimoto H, et al. Physiological levels of tumstatin, a fragment of collagen IV alpha3 chain, are generated by MMP-9 proteolysis and suppress angiogenesis via alphaV beta3 integrin. Cancer Cell 2003;3:589-601.

158. Collins J, Horn N, Wadenback J, Szardenings M. Cosmixplexing: a novel recombinatorial approach for evolutionary selection from combinatorial libraries. J Biotechnol 2001; 74:317-38.

159. Brody EN, Gold L. Aptamers as therapeutic and diagnostic agents. J Biotechnol 2000; 74:5-13.

160. Vater A, Klussmann S. Toward third-generation aptamers: spiegelmers and their therapeutic prospects. Curr Opin Drug Discov Devel 2003; 6:253-61.

161. Hauff P, Stephens A, Braeutigam M. New imaging probes. In: Debatin JF, Hricak H, Niendorf HP, Esser M, editors. MRI: from current knowledge to new horizons. The Netherlands: Excerpta Medica Medical Communications BV; 2003.
162. Arkin MR, Wells JA. Small-molecule inhibitors of protein-protein interactions: progressing towards the dream. Nat Rev Drug Discov 2004; 3:301-17.

163. Mammen M, Choi S-K, Whitesides GM. Polyvalent interactions in biological systems: implications for design and use of multivalent ligands and inhibitors. Angew Chem Int Ed 1998; 37:2754-94.

164. Shuker SB, Hajduk PJ, Meadows RP, Fesik SW. Discovering high-affinity ligands for proteins: SAR by NMR. Science 1996; 274:1531-4.

165. Ramstrom O, Lehn JM. Drug discovery by dynamic combinatorial libraries. Nat Rev Drug Discov 2002; 1:26-36.

166. Erlanson DA, Lam JW, Wiesmann C, et al. In situ assembly of enzyme inhibitors using extended tethering. Nat Biotechnol 2003; 21:308-14.

167. Melkko S, Scheuermann J, Dumelin CE, Neri D. Encoded self-assembling chemical libraries. Nat Biotechnol 2004; 22:568-74.

168. Supuran CT, Scozzafava A, Casini A. Carbonic anhydrase inhibitors. Med Res Rev 2003; 23:146-89.

169. Chrastina A, Pastorekova S, Pastorek J. Immunotargeting of human cervical carcinoma xenograft expressing CA IX tumor-associated antigen by ${ }^{125}$ I-labeled M75 monoclonal antibody. Neoplasma 2003; 50:13-21.

170. Chrastina A, Zavada J, Parkkila S, et al. Biodistribution and pharmacokinetics of ${ }^{125}$ I-labeled monoclonal antibody M75 specific for carbonic anhydrase IX, an intrinsic marker of hypoxia, in nude mice xenografted with human colorectal carcinoma. Int J Cancer 2003; 105:873-81. 